\title{
Clinical, Radiographic, and Histologic Evaluation of Maxillary Sinus Lift Procedure Using a Highly Purified Xenogenic Graft (Laddec $^{\circledR}$ )
}

\section{Renzo Guarnieri ${ }^{1}$, Fabrizio Belleggia ${ }^{2}$, Stefano Ippoliti $^{3}$, Patrica DeVilliers ${ }^{4}$, Luigi Vito Stefanelli ${ }^{1}$, Stefano Di Carlo ${ }^{1}$, Giorgio Pompa ${ }^{1}$}

${ }^{1}$ Department of Dental and Maxillofacial Sciences, School of Dentistry, University La Sapienza, Roma, Italy.

${ }^{2}$ Private Implant Practice, Roma, Italy.

${ }^{3}$ Private Prosthesis Practice, Roma, Italy.

${ }^{4}$ Oral and Maxillofacial Pathology, Pathology Associates of Alabama, Birmingham, Alabama, USA.

\author{
Corresponding Author: \\ Renzo Guarnieri \\ Via Deserto di Gobi 85 A, 00144 Roma \\ Italy \\ E-mail: renzoguarnieri@gmail.com
}

\begin{abstract}
Objectives: The aim of this study was to evaluate the clinical, radiographic and histologic results when a highly purified xenogenic bone $\left(\operatorname{Laddec}^{\circledR}\right.$ ) was used as grafting material in maxillary sinuses.

Material and Methods: In fifteen patients requiring unilateral maxillary sinus augmentation, the grafting procedure was performed with Laddec ${ }^{\circledR}$. Forty-two implants were installed after a 6 month healing period. The height of the augmented sinus was measured radiographically immediately after augmentation and postoperatively up to 36 months. At the time of implant placement, a bone core was harvested in each patient for histological examination.

Results: The cumulative implant survival rate was 97.6\%. The original height was 3.65 (SD 0.7) mm and the augmented sinus height was 13.8 (SD 1.4) $\mathrm{mm}$ after the surgery. The reduced height of grafted xenogenic material (RDL) at the implant insertion was 0.83 (SD 0.38) $\mathrm{mm}$, and at the final postoperative visit was 0.91 (SD 0.25) $\mathrm{mm}$, showing no significant correlation with the follow-up periods by Spearman's test $(\mathrm{P}=0.118)$. In addition, no significant difference in the RDL was observed according to the site of implantation $(\mathrm{P}=0.682)$. The mean implant marginal bone loss was $0.38(\mathrm{SD} 0.24) \mathrm{mm}$. Histological analysis showed the bone cores were composed of 64.72 (SD 3.44)\% newly formed bone, 17.41 (SD 2.02)\% connective tissue, 16.93 (SD 2.83)\% residual graft particles, and 0.94 (SD 0.11$) \%$ inflammatory cells.

Conclusions: According to our data, the highly purified xenogenic bone (Laddec ${ }^{\circledR}$ ), used as graft material in the sinus lift procedure, may create adequate bone volume, and appropriate osseointegration of dental implants.
\end{abstract}

Keywords: bone; bone replacement materials; bone substitutes; maxillary sinus floor augmentation; osteogenesis; sintered bovine bone.

Accepted for publication: 1 March 2016

To cite this article:

Guarnieri R, Belleggia F, Ippoliti S, DeVilliers P, Stefanelli LV, Di Carlo S, Pompa G.

Clinical, Radiographic, and Histologic Evaluation of Maxillary Sinus Lift Procedure Using a Highly Purified Xenogenic Graft $\left(\right.$ Laddec $\left.^{\circledR}\right)$

J Oral Maxillofac Res 2016;7(1):e3

URL: http://www.ejomr.org/JOMR/archives/2016/1/e3/v7n1e3.pdf

doi: $10.5037 /$ jomr.2016.7103 


\section{INTRODUCTION}

A maxillary sinus lift procedure is an established method used to provide a sufficient bone volume for implant placement in patients with a severely atrophied posterior maxilla [1-3]. The use of autogenous bone in sinus augmentation is believed to be a superior method because of the reproducible healing mechanism of osteogenesis, osteoinduction, and osteoconduction. However, some important disadvantages, such as the need for additional surgical sites, the associated morbidity, and the rapid resorption rate when autogenous bone is used as a sinus grafting material [4-6], have led many surgeons to use other materials including derived bovine bone $[\underline{7}, \underline{8}]$. Graft materials consisting of deproteinized, sterilized, bovine bone, are reported by several studies to be osteoconductive and well integrated in the host site with very low resorbability [9-18].

Recently, a highly purified, bovine bone derived graft $\left(\right.$ Laddec $\left.^{\circledR}\right)$ has been introduced to clinicians for its innovative features. It is a xenograft consisting of deproteinized, sterilized bovine bone, characterized by the preservation of a collagen type I matrix, associated with spindle-shaped hydroxyapatite crystals. Unlike other commercially available bovine derived biomaterials in which all the organic phase is chemically removed using ethylene diamine treatment and heating, followed by extensive washing and heating below $600{ }^{\circ} \mathrm{C}$ (U.S. patent 5,167,961), Laddec $^{\circledR}$ is obtained from bovine bone after extensive washing with distilled water and a phosphate buffer $(0.4 \mathrm{M}, \mathrm{pH} 7.4)$, followed by defatting at a temperature $<50{ }^{\circ} \mathrm{C}$ with ethanol/dichloromethane and proteoglycan removal by urea and mercaptoethanol (International patent: PCT/WO/91/07194). This process has previously been shown to preserve the collagen type I fibres in the matrix of the xenograft [7], which seem to play a crucial role in cell attachment, as well as the spreading and orientation of osteoblasts, as collagen type I can bind osteoblasts via specific cell surface receptors, the integrins $[19,20]$. In addition to the maintenance of the collagen fibres, Laddec ${ }^{\circledR}$ presents physical characteristics very similar to human cancellous bone, with an average thickness of trabecules of $164.8(35.1) \mu \mathrm{m}$, an intertrabecular separation (porosity) of $342.9(105.6) \mu \mathrm{m}$, and $2(0.4)$ trabecules per $\mathrm{mm}$ [21].

Preclinical studies have already shown the capacity of Laddec $^{\circledR}$ to stimulate osteoblastic activity, facilitating the formation of multiple cell layers, and to increase the expression of alkaline phosphatase in mesenchymal cell cultures [20-22].
Furthermore, subsequent clinical and histological studies in humans indicated that the processing methodology of $\operatorname{Laddec}^{\circledR}$ is safe, as the biomaterial does not induce Laddec ${ }^{\circledR}$ immunologic response, and it represents a reliable option in oral and maxillofacial surgery procedures $[\underline{23}, \underline{24}]$.

The aim of this study was to evaluate the clinical, radiographic and histologic results when highly purified xenogenic bone $\left(\operatorname{Laddec}^{\circledR}\right)$ was used as a grafting material in maxillary sinuses.

\section{MATERIAL AND METHODS Patients}

Fifteen patients ( 8 males and 7 females, aged from 48 to 66 years, with a mean of 58 [5.2] years), with a severely atrophied posterior maxilla, participated in this study. This study used a retrospective clinical database of information about patients who were previously treated as part of an approved research protocol (University Ethical Committee approbation \#7413). All patients signed a written informed consensus, and the study was conducted according to the principles of the Declaration of Helsinki on experimentation involving human subjects.

Inclusion criteria were: 1) presence of maxillary partial edentulism involving the premolar/molar areas; 2) the presence of a residual alveolar ridge height less than $5 \mathrm{~mm}$; 3) patients in which primary implant stability could not be established. Exclusion criteria were: 1) smoking more than 10 cigarettes/day; 2) systemic diseases or maxillary sinus pathology; 3 ) recent extractions in the involved area.

A thorough preoperative evaluation, including the studying the mounted diagnostic cast and diagnostic wax-up, was performed. Radiograph examination included both intraoral and computerized tomography. Preoperative medications included amoxicillin, and $1 \mathrm{~g}$ twice a day of clavulanic acid (NeoDuplamox, Procter \& Gamble), starting 1 day prior to surgery and continuing until 8 days post-surgery. Patients were asked to rinse with $0.2 \%$ chlorhexidine gluconate at the surgery and twice a day for 14 days after the procedure.

\section{Surgical protocol}

Under local anaesthesia, a crestal incision was made slightly toward the palatal aspect and throughout the entire length of the edentulous segment, supplemented by buccal releasing incisions mesially and distally. Full thickness flaps were elevated to expose the alveolar crest and the lateral wall of the maxillary sinus (Figure 1). 


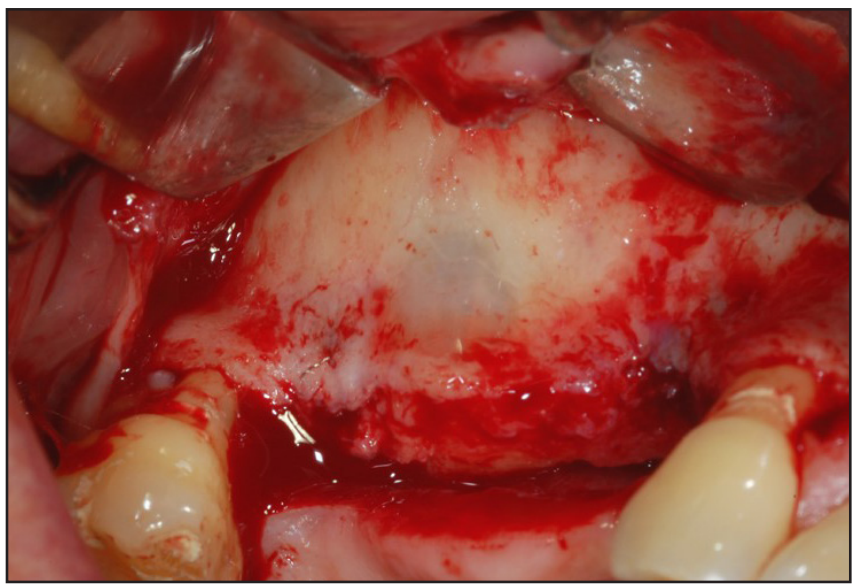

Figure 1. Full thickness flap elevated to expose the alveolar crest and the lateral wall of the maxillary sinus.

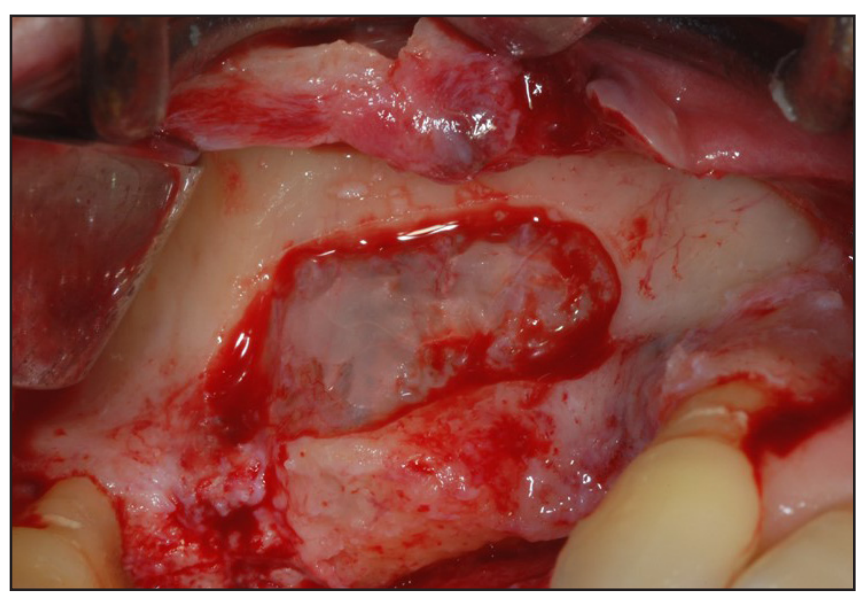

Figure 2. A trap door made in the lateral sinus wall.

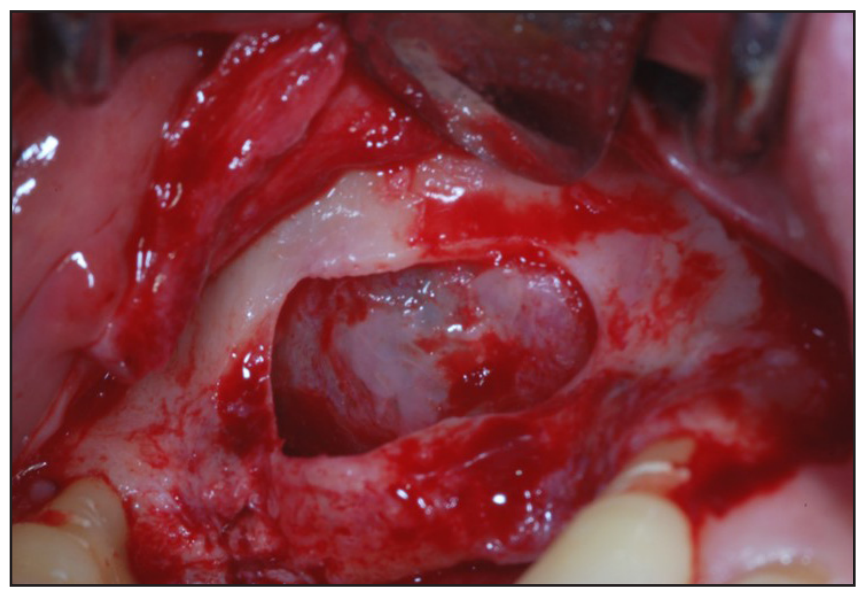

Figure 3. The door was rotated inward and upward with a top hinge to a horizontal position.

Using a round burr under cold $\left(4-5{ }^{\circ} \mathrm{C}\right)$ sterile saline irrigation, a trap door was made in the lateral sinus wall (Figure 2). The door was rotated inward and upward with a top hinge to a horizontal position (Figure 3). The sinus membrane was lifted with elevator instruments of different shapes until it became completely detached from the lateral

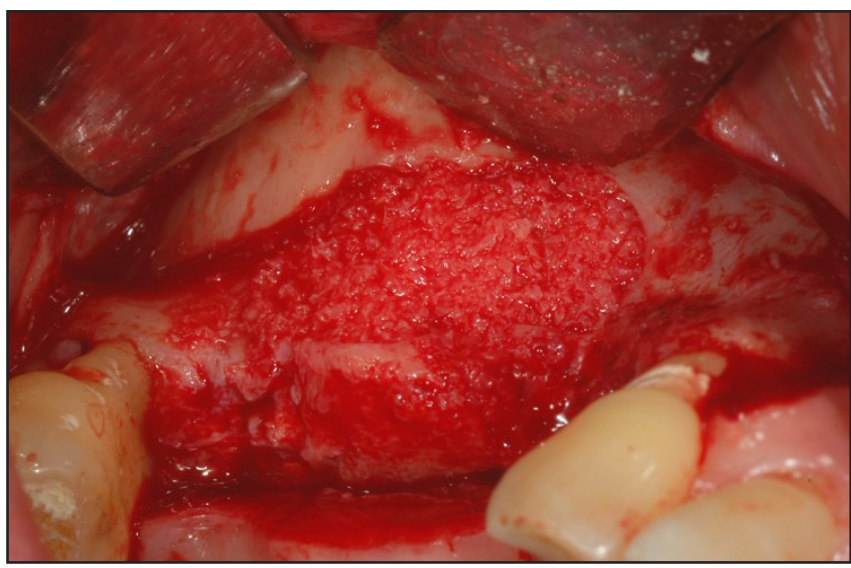

Figure 4. The Laddec ${ }^{\circledR}$ particles mixed with sterile saline solution and carefully packed in the sinus cavity.

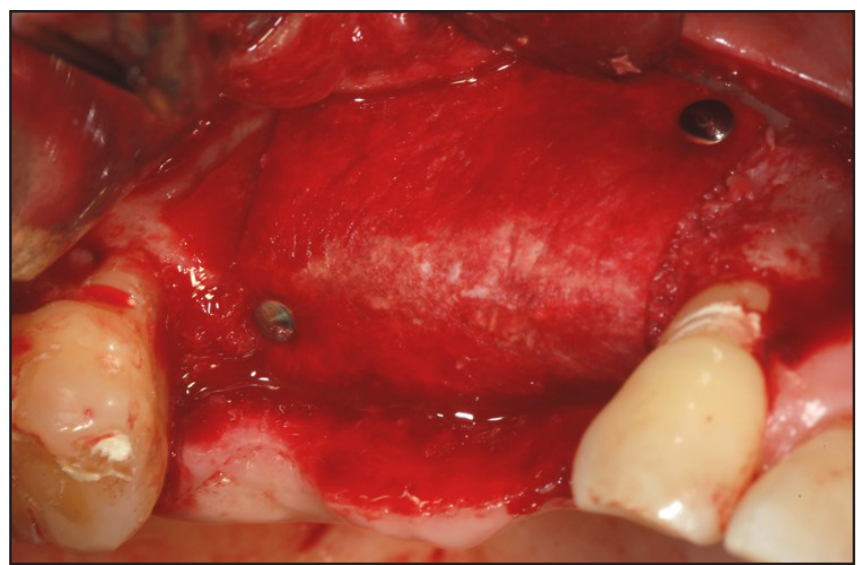

Figure 5. A cross-linked collagen membrane positioned against the packed sinus window and folded over.

and inferior walls of the sinus. Small tears in the membrane were covered with a cross-linked collagen membrane (Mem-Lok ${ }^{\circledR}$, BioHorizons, Birmingam, Alabama, USA), before graft placement to avoid the possible complication of sinusitis from the migration of granules towards the middle meatus with its obstruction.

The Laddec $^{\circledR}$ (BioHorizons, Birmingam, Alabama, USA) particles were mixed with sterile saline solution and carefully packed in the sinus cavity using a plugger (Figure 4). The quantity of Laddec ${ }^{\mathbb{B}}$ needed for each augmentation varied from 3 to $5 \mathrm{~g}$. A membrane (Mem-Lok ${ }^{\circledR}$, BioHorizons, Birmingam, Alabama, USA) was positioned against the packed sinus window and was folded over (Figure 5). The mucoperiosteal flap was then replaced and sutured with multiple horizontal mattress sutures (Figure 6). Sutures were removed 2 weeks after surgery (Figure 7). Postsurgical visits were scheduled at monthly intervals to check the course of healing.

The sinus was allowed to heal for 6 months, and then Laser-Lok $^{\circledR}$ BioHorizons implants (BioHorizons, Birmingam, Alabama, USA) were placed. 


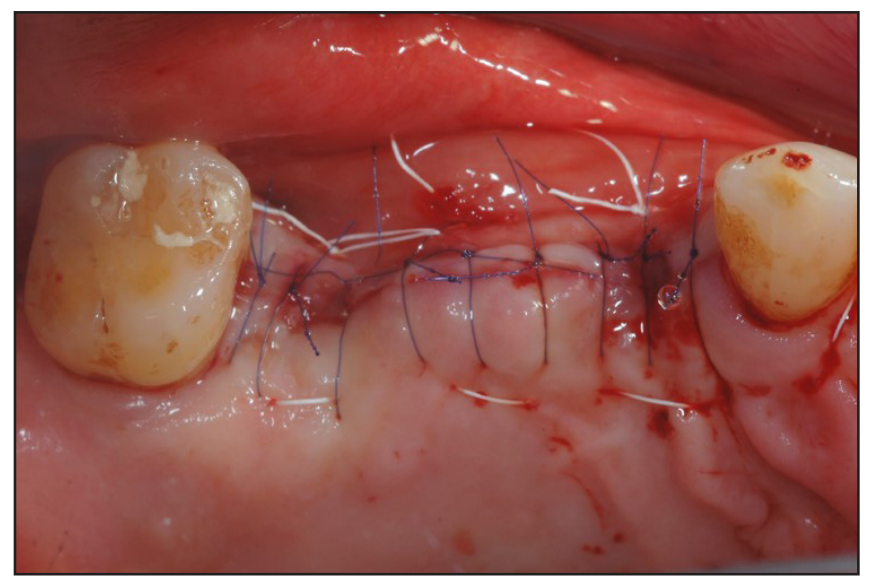

Figure 6. The mucoperiosteal flap replaced and sutured with multiple sutures.

\section{Radiographic analysis}

Radiographic analysis was performed using intraoral radiographs and computerized tomography (Figures 8 and 9). At least 3 computerized topographies

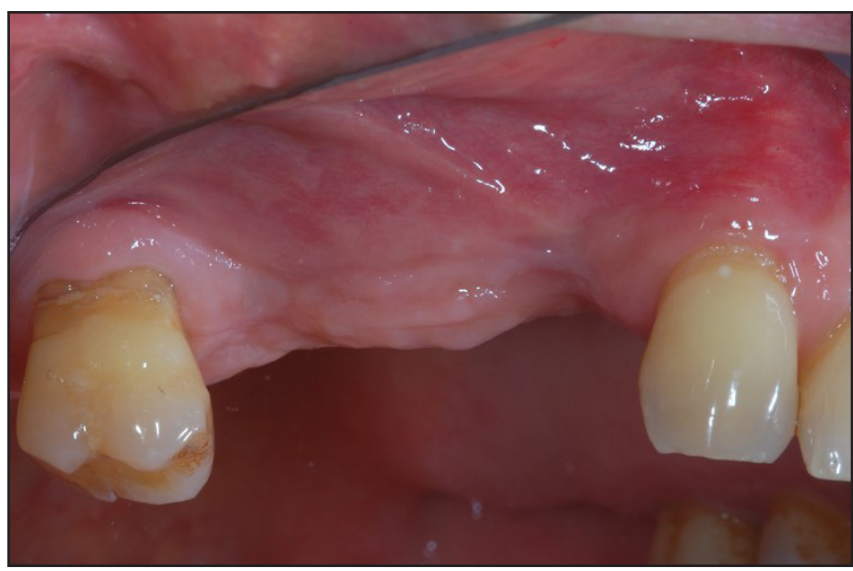

Figure 7. Sutures removed 2 weeks after surgery.

were taken, one immediately before and one after the sinus augmentation, and another one up to 3 years after the surgery. Intraoral radiographs were obtained every 6 months through the follow-up period. The linear measurements taken from radiographs were described below.

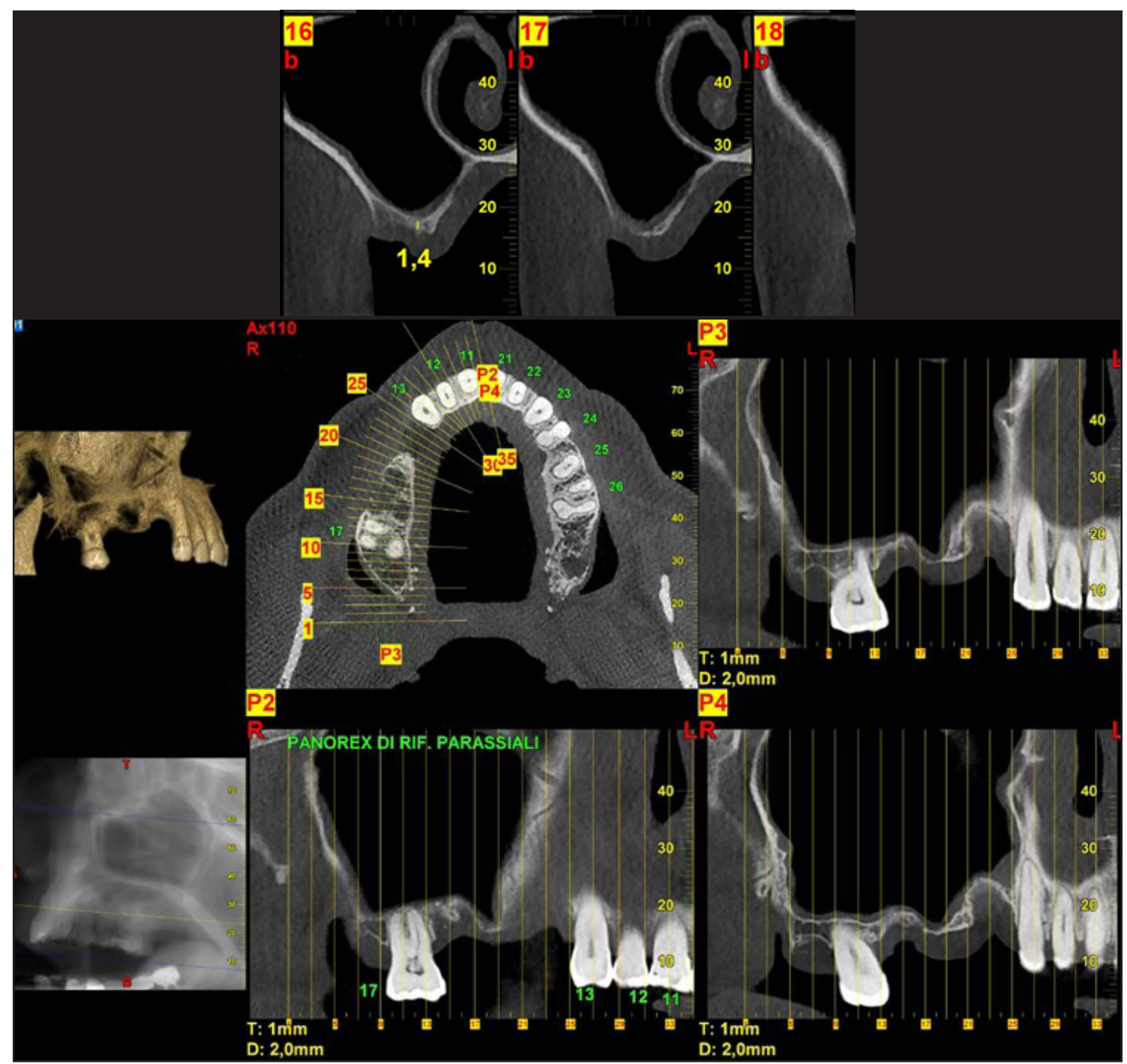

Figure 8. Preoperative computerized tomography. 


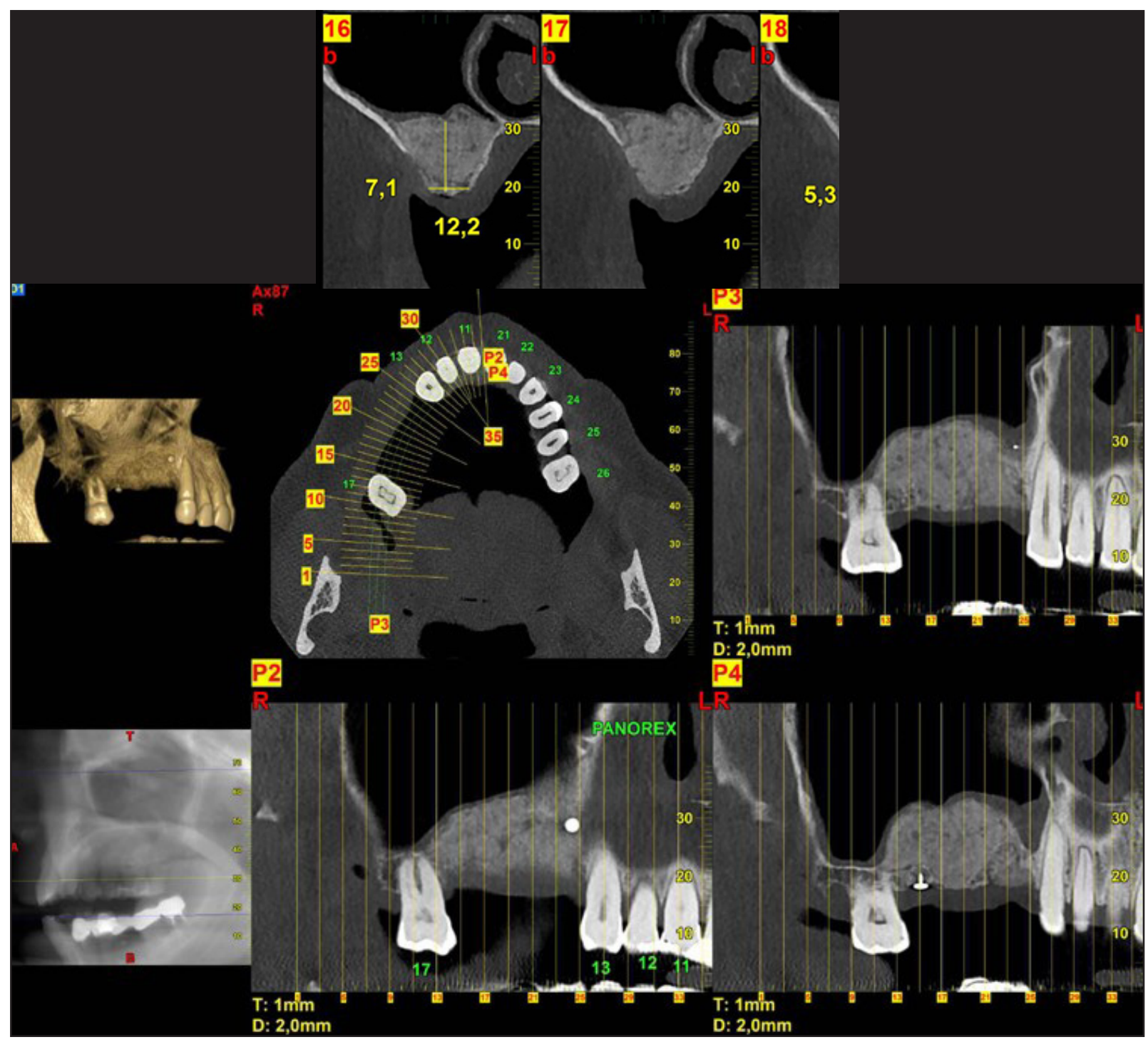

Figure 9. Postoperative computerized tomography.

The original alveolar bone heights prior to the surgery, from the alveolar crest to the base of the sinus, were measured. The augmented sinus heights (ASH) were measured from the 1 st bone to implant contact points to the base of the maxillary sinus, which had been elevated with Laddec $^{\circledR}$ at the mesial and distal aspects of the implants. The marginal bone loss (MBL) was determined by comparing the intraoral radiographs immediately taken after the surgery and up to 3 years after implant loading. The reduced height of Laddec ${ }^{\mathbb{B}}$ (RDL) was calculated based on the changes in the ASH and MBL.

\section{Histologic analysis}

At time of the implant surgery, bone cores were harvested using a 3.5 x $10 \mathrm{~mm}$ diameter trephine under cold $\left(4-5{ }^{\circ} \mathrm{C}\right)$ sterile saline solution irrigation. The bone specimens were immediately fixed in $10 \%$ buffered formalin and embedded in

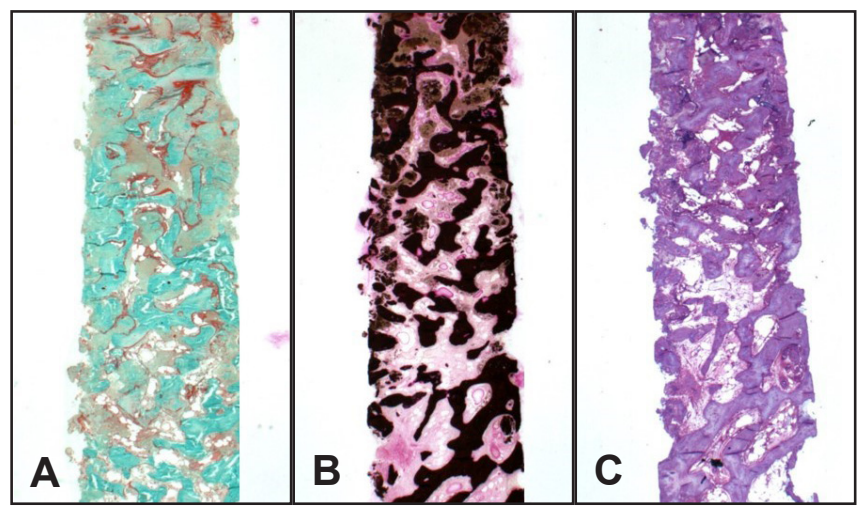

Figure 10. Bone core specimens: $\mathrm{A}=$ Trichrome stain; $\mathrm{B}=$ Von Kossa stain; $\mathrm{C}=$ Methylene Blue and Basic Fuschin stain. Original magnification $\times 1.25$.

a glycolmethacrylate resin. After polymerization, specimens were sectioned along their longitudinal axis to a thickness of 70 microns (Laddec ${ }^{\circledR}$ plastic Microtome, RM 2265). Slides were stained with trichrome, methilyne blue, and Von Kossa (Figure 10). 
Slides were examined using an Olympus B51 microscope. The histomorphometry was performed using Bioquant ${ }^{\mathbb{R}}$ image analysis software (R\&M Biometrics, Nashville, TN, USA) and images were captured with a Q-Imaging camera, 32-0013B-157, RETIGA, Colour 12-bit (Figures 11 and 12).

\section{Statistical analysis} Mean values for all measurements were calculated. Chicago, IL, USA) was used for all statistical analysis.
Differences in RDL according to the timing of implantation were analysed using an independent t-test. A one-way analysis of variance was used to evaluate the differences in RDL according to the implant sites. Correlation between the RDL and follow-up period were determined by Spearman's test. Parametric data were expressed as mean and standard deviation (SD). Statistical significance level was defined at $\mathrm{P}=0.05$. SPSS ver. 12.0.0 (SPSS Inc.,

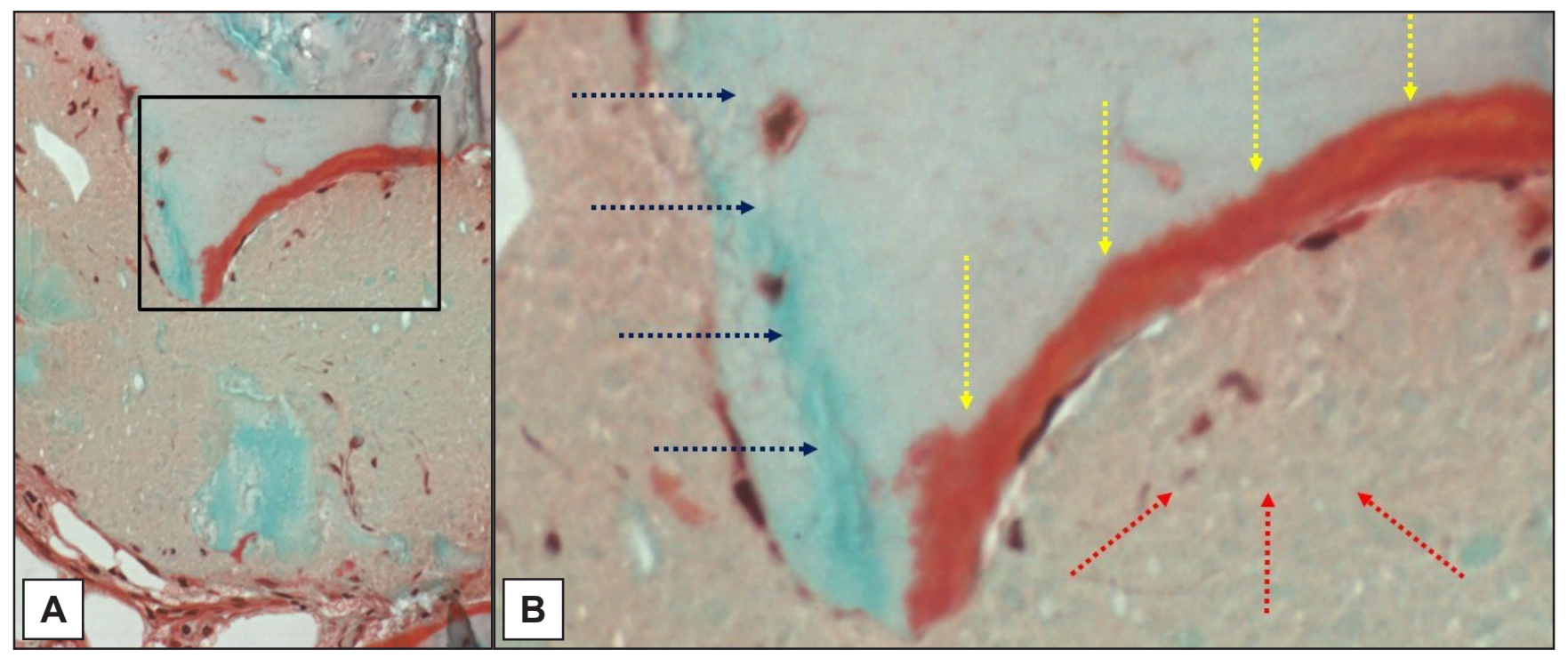

Figure 11. Trichrome stain of the osteoid rim and graft material: $\mathrm{A}=$ original magnification $\mathrm{x} 20 ; \mathrm{B}=$ original magnification $\mathrm{x} 100$. Red osteoid rim (yellow arrows) green viable bone (blue arrows) and graft material (red arrows).

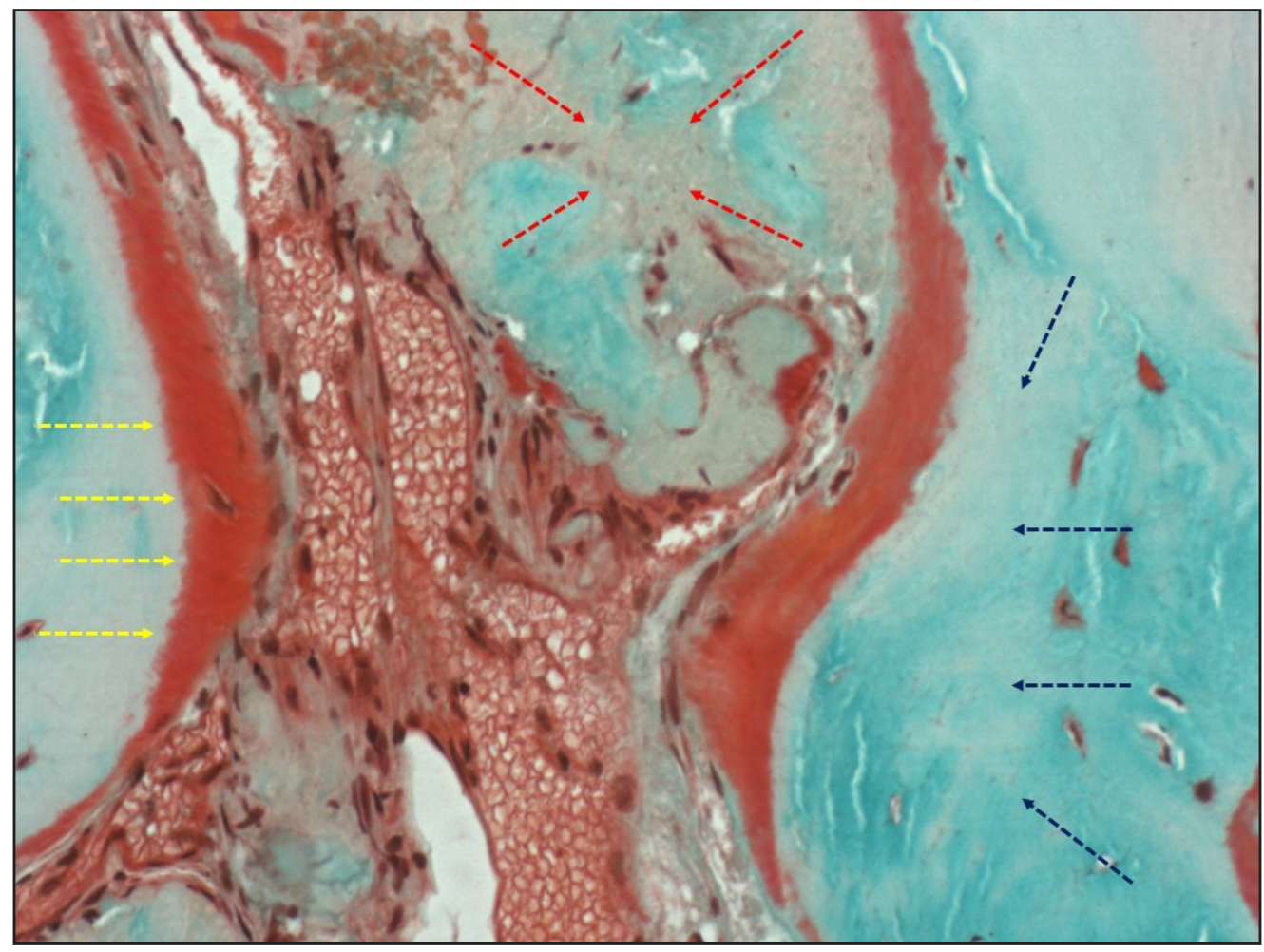

Figure 12. Trichrome stain of osteoid (original magnification x40). Red osteoid rim (yellow arrows) green viable bone (blue arrows) and graft material (red arrows). 


\section{RESULTS \\ Clinical results}

No complications, including wound dehiscence, were observed in any of the patients. One of the 42 implants was removed between implantation and the follow-up period. This implant was successfully restored by wider diameter implant. The 0 to 6 month cumulative implant survival rate was $97.6 \%$, and this value continued to 36 months.

\section{Radiographic results}

The mean follow-up period for implants after the sinus augmentation was 28.4 (3.2) months (range 24 to 36 months). The original sinus height was a mean of $3.65(0.7) \mathrm{mm}$ (range 1.4 to $4.6 \mathrm{~mm}$ ) and the augmented sinus height was a mean of 13.8 (2.4) $\mathrm{mm}$ (range 9.5 to $16.7 \mathrm{~mm}$ ) after the surgery. The mean implant marginal bone loss up to 30 months after loading was $0.38(0.24) \mathrm{mm}$. The RDL 1 year postoperatively was $0.83(0.38) \mathrm{mm}$, and at 3 years postoperatively was $0.91(0.25) \mathrm{mm}$. No significant correlation was noted between the RDL and followup periods by Spearman's test $(\mathrm{P}=0.118)$. In addition, no significant difference in the RDL was observed according to the site of implantation $(\mathrm{P}=0.682)$.

\section{Histologic and histomorphometric results}

Microscopic examination of all the processed bone core specimens showed newly formed bone, in close contact with the xenogenic graft particles. No gaps were found at the bone-graft interface. Most of the graft particles were surrounded by newly formed bone, and in some areas, the graft particles were in contact with marrow spaces. The presence of non-mineralized matrix (osteoid seam) was also observed at the interface with the xenograft, which was strongly stained by Von Kossa; the osteoid was surfaced by a rim of osteoblasts (Figures 11 and 12). The newly formed bone abutting the graft particles showed well-organized lamellae, and numerous lacunae with osteocytes. No acute inflammatory infiltrate or foreign body granulomatous tissue was evident. Histomorphometric analysis showed the bone cores were composed of 64.72 (3.44)\% newly formed bone, 17.41 (2.02)\% connective tissue, 16.93 $(2.83) \%$ residual graft particles, and $0.94(0.11) \%$ inflammatory cells. Histomorphometric mean data are reported in Table 1.
Table 1. Histomorphometric mean data of bone core specimens

\begin{tabular}{|c|c|c|}
\hline & Bone core & SD \\
\hline Tt. tissue area $\left(\mathrm{mm}^{2}\right)$ & 12.01 & 1.9 \\
\hline Tt. area of bone $\left(\mathrm{mm}^{2}\right)$ & 7.31 & 0.8 \\
\hline Tt. area of bone graft $\left(\mathrm{mm}^{2}\right)$ & 1.85 & 0.3 \\
\hline$\%$ connective tissue/Tt. area & 17.41 & 2.02 \\
\hline$\%$ bone/Tt. tissue area & 64.72 & 3.44 \\
\hline$\%$ graft $/$ Tt. tissue area & 16.93 & 2.83 \\
\hline Tt. osteoid area $\left(\mathrm{mm}^{2}\right)$ & 0.017 & 0.004 \\
\hline Tt. connective tissue area $\left(\mathrm{mm}^{2}\right)$ & 0.647 & 0.194 \\
\hline Tt. bone marrow area $\left(\mathrm{mm}^{2}\right)$ & 1.323 & 0.332 \\
\hline Tt. bone surface (mm) & 84.87 & 9.81 \\
\hline Tt. osteoid surface (mm) & 1.791 & 0.64 \\
\hline$\%$ osteoid/Tt. bone surface & 2.16 & 0.72 \\
\hline Trabecular thickness (um) & 170.03 & 18.5 \\
\hline Trabecular number $\left(\mathrm{mm}^{-1}\right)$ & 3.583 & 0.74 \\
\hline Trabecular space (um) & 102.8 & 21.3 \\
\hline$\%$ inflammatory cells/Tt. tissue area & 0.94 & 0.11 \\
\hline
\end{tabular}

$\mathrm{SD}=$ standard deviation; $\mathrm{Tt} .=$ total biopsy core.

\section{DISCUSSION}

Technological evolution and better understanding of bone-healing biology have helped to clarify the optimum makeup of xenogenic bone substitute, including the source, preparation methods, and particle size, in order to improve their osteoconductive potential. When associated with the refinement of the sinus lift surgical technique occurred in recent years, this allows for predictable placement of implants in atrophic maxillae bone regenerated with xenografts $[10,25, \underline{26}]$. In the present study, the survival rate of implants placed after a sinus augmentation procedure was $97.6 \%$, which is comparable with the pre-existing literature data [25,27-29] despite the small sample size. In addition, radiographic evaluation showed the graft material, was well maintained in the sinus and only decreased slightly over a 3 year period, demonstrating that Laddec $^{\circledR}$ is a clinically suitable material for sinus augmentation. Despite the clinical success of xenogenic graft materials, few histomorphometric studies are reported in the published literature [30,31]. The purpose of our histologic and histomorphometric evaluation is to understand the interactions that occur between the bone and the graft. In all the histological sections examined in the present study, no evidence of acute inflammatory infiltrate, or foreign body granulomatous tissue was found. This indicates that the processing methodology of $\operatorname{Laddec}^{\circledR}$ is safe, 
as the biomaterial does not induce adverse immunologic response. In addition, the regenerated bone has shown that $\operatorname{Laddec}^{\circledR}$, is mostly reabsorbed after 6 months, replaced by vital bone, and the residual xenograft particles are integrated to vital bone. Histological analysis showed the bone cores were composed of $64.72(3.44) \%$ newly formed bone, $17.41(2.02) \%$ connective tissue, 16.93 $(2.83) \%$ residual graft particles, and $0.94(0.11) \%$ inflammatory cells. The $16.93 \%$ residual graft particles indicate that, after 6 months, the graft material is almost all reabsorbed and replaced by newly regenerated bone. These data are particularly significant because it is known that to maintain the osseointegration of the implant over the time, a presence of reactive tissue able to undergo a sustained state of remodelling is needed [32]. Several studies have suggested that differing methods of xenograft preparation can cause differences in efficacy [33,34] and in reabsorption time $[9,35,36]$. Orsini et al. [3] reported that bovine bone derived graft material in which all the organic phase is chemically removed $\left(\right.$ Bio-Oss $\left.{ }^{\circledR}\right)$ after 6 months does not show signs of resorption. Same authors reported identical histological results also for porcine derived bone substitute with no evidence at 6 months of biomaterial resorption [36]. In our opinion, the differences between the histologic results of the present study and those reported by these other studies might be related to the specific chemical/physical features of the graft materials, and the events occurring after biomaterial implantation. When a graft material is implanted in bone, the healing process is characterized by two phases: 1) the response of the host to the biomaterial; and 2) the behaviour of the material in the host $[\underline{37}, \underline{38}]$. A non-specific action occurs in the first phase: a blood clot is formed in the injured area where the outer area of the local bone becomes necrotic, the capillaries start to develop, and migration of inflammatory cells e.g. lymphocytes, granulocytes and monocytes occurs. These actions restore blood flow, activate an inflammatory response after 1 - 3 days, and start to form granulation tissue. The granulation tissue will mature to a collagen matrix and mesenchymal stem cells begin to differentiate into osteoblasts cells. A more specific action occurs during the second phase depending on the ability of osteoblastic cells to migrate into the biomaterial and on the relationships they establish between their membrane and the biomaterial surface. Adhesion, proliferation, migration, and differentiation of mesenchymal stem cells at the surface of grafted materials are related to the ability of membrane receptors to bind molecules of the extracellular matrix.
Among the membrane receptors, integrins are transmembrane $\alpha \beta$ heterodimer proteins known to play a key role in the cellular adhesion [39-41]. In bone, the b1-integrin subunit is shared by several integrins in osteoblasts [42-45]. Specifically, the b1-subunit is involved in adhesion of osteoblasts to collagen type I and is supposed to play a role in osteoblast morphology. Previous in vitro studies highlighted the importance of preserving the collagen matrix in the xenograft material $[\underline{19}, \underline{20}]$. Comparing two different types of bovine derived bone graft materials, with similar architectural organization, morphological surface topography and roughness index, but with different chemical composition of their matrices, $\left(\right.$ Laddec $^{\circledR}$ characterized by preservation of the mineralized collagen matrix, and Bio-Oss ${ }^{\circledR}$, characterized by complete deproteinization which only preserves the mineral phase), Balsè et al. [19] reported that osteoblast-like cells cultured at the surface of the two bone xenogenic biomaterials have their orientation mainly influenced by the chemical nature of the underlying surface. At the surface of the collagen-containing matrix $\left(\right.$ Laddec $\left.^{\mathbb{R}}\right)$, cells exhibited an elongated shape and oriented axis parallel to the underlying collagen bundles. In contrast, at the surface of the single mineral matrix $\left(\right.$ Bio-Oss $\left.{ }^{\circledR}\right)$, cells were round shaped with random disposition. The b1-integrin subunit, detected with an immunogold method at the transmission electron microscopic level, was found localized at the outer surface of cells, in close association with mineralized collagen matrix, and at the contact points between cells and biomaterials. In contrast, at the surface of the single mineral matrix (Bio-Oss ${ }^{\circledR}$ ), cells were round-shaped with random disposition and without association with deproteinized matrix. The importance of preserving the collagen matrix in the xenograft material, has also been reported by another in vitro study [22], in which authors reported that mesenchymal stem cells, growing on the highly purified bovine xenograft granules, exhibit a high seeding efficiency, a good proliferation, and an early expression of membrane (vesicles) specializations, presumably due to the process of mineralisation since X-ray microanalysis showed the presence of calcium. Although in vitro studies must be interpreted with caution since they cannot recreate the complex interactions of cells in vivo, those studies indicated the presence of collagen fibres in the matrix of a bone xenogenic biomaterial appears to be the major element in determining early cell disposition, and perhaps further cell functions such as orientation of new matrix deposition. Histomorphometric analysis in the present study add further information for understanding the Laddec $^{\circledR}$ 
xenograft integration process in the bone site, and interactions that occured seem to sustain the validity of previously reported data. However, further study and additional long-term histologic analyses are needed to confirm our results.

\section{CONCLUSIONS}

Within the limitation of the present study, it can be suggested that the highly purified xenogenic bone substitute Laddec $^{\circledR}$ may have predictable results when used as a grafting material for maxillary sinus lift procedures due to its excellent osteoconductive properties.

\section{ACKNOWLEDGMENTS AND DISCLOSURE STATEMENTS}

This work was partially supported by BioHorizons, Birmingham, Alabama, USA.

\section{REFERENCES}

1. Esposito M, Felice P, Worthington HV. Interventions for replacing missing teeth: augmentation procedures of the maxillary sinus. Cochrane Database Syst Rev. 2014 May 13;5:CD008397. [Medline: 24825543] [doi: 10.1002/14651858.cd008397.pub2]

2. Del Fabbro M, Wallace SS, Testori T. Long-term implant survival in the grafted maxillary sinus: a systematic review. Int J Periodontics Restorative Dent. 2013 Nov-Dec;33(6):773-83. [Medline: 24116362] [doi: 10.11607/prd.1288]

3. Duttenhoefer F, Souren C, Menne D, Emmerich D, Schön R, Sauerbier S. Long-term survival of dental implants placed in the grafted maxillary sinus: systematic review and meta-analysis of treatment modalities. PLoS One. 2013 Sep 18;8(9):e75357. [Medline: 24058679] [PMC free article: 3776785] [doi: 10.1371/journal.pone.0075357]

4. Hallman M, Hedin M, Sennerby L, Lundgren S. A prospective 1-year clinical and radiographic study of implants placed after maxillary sinus floor augmentation with bovine hydroxyapatite and autogenous bone. J Oral Maxillofac Surg. 2002 Mar;60(3):277-84; discussion 285-6. [Medline: 11887139] [doi: 10.1053/joms.2002.30576]

5. Johansson B, Grepe A, Wannfors K, Hirsch JM. A clinical study of changes in the volume of bone grafts in the atrophic maxilla. Dentomaxillofac Radiol. 2001 May;30(3):157-61. [Medline: 11420628] [doi: 10.1038/sj.dmfr.4600601]

6. Misch CE, Dietsh F. Bone-grafting materials in implant dentistry. Implant Dent. 1993 Fall;2(3):158-67. [Medline: 8142935] [doi: 10.1097/00008505-199309000-00003]

7. Block JE, Poser J. Does xenogeneic demineralized bone matrix have clinical utility as a bone graft substitute? Med Hypotheses. 1995 Jul;45(1):27-32. [Medline: 8524172] [doi: 10.1016/0306-9877(95)90195-7]

8. Jensen SS, Aaboe M, Pinholt EM, Hjørting-Hansen E, Melsen F, Ruyter IE. Tissue reaction and material characteristics of four bone substitutes. Int J Oral Maxillofac Implants. 1996 Jan-Feb;11(1):55-66. [Medline: 8820123]

9. Valentini P, Abensur D. Maxillary sinus floor elevation for implant placement with demineralized freeze-dried bone and bovine bone (Bio-Oss): a clinical study of 20 patients. Int J Periodontics Restorative Dent. 1997 Jun;17(3):232-41. [Medline: 9497715 ]

10. Valentini P, Abensur D, Densari D, Graziani JN, Hämmerle C. Histological evaluation of Bio-Oss in a 2-stage sinus floor elevation and implantation procedure. A human case report. Clin Oral Implants Res. 1998 Feb;9(1):59-64. [Medline: 9590946] [doi: 10.1034/j.1600-0501.1998.090108.x]

11. Davies JE. In vitro modeling of the bone/implant interface. Anat Rec. 1996 Jun;245(2):426-45. [Medline: 8769677$]$ [doi: 10.1002/(SICI) 1097-0185(199606)245:23.0.CO;2-Q]

12. Proussaefs P, Lozada J, Kleinman A, Rohrer MD, McMillan PJ. The use of titanium mesh in conjunction with autogenous bone graft and inorganic bovine bone mineral (bio-oss) for localized alveolar ridge augmentation: a human study. Int J Periodontics Restorative Dent. 2003 Apr;23(2):185-95. [Medline: 12710822]

13. Haas R, Donath K, Födinger M, Watzek G. Bovine hydroxyapatite for maxillary sinus grafting: comparative histomorphometric findings in sheep. Clin Oral Implants Res. 1998 Apr;9(2):107-16. [Medline: 9663038]

14. Berglundh T, Lindhe J. Healing around implants placed in bone defects treated with Bio-Oss. An experimental study in the dog. Clin Oral Implants Res. 1997 Apr;8(2):117-24. [Medline: 9758962] [doi: 10.1034/j.1600-0501.1997.080206.x]

15. Haas R, Mailath G, Dörtbudak O, Watzek G. Bovine hydroxyapatite for maxillary sinus augmentation: analysis of interfacial bond strength of dental implants using pull-out tests. Clin Oral Implants Res. 1998 Apr;9(2):117-22. [Medline: 9663039] [doi: 10.1034/j.1600-0501.1998.090207.x]

16. McAllister BS, Margolin MD, Cogan AG, Taylor M, Wollins J. Residual lateral wall defects following sinus grafting with recombinant human osteogenic protein-1 or Bio-Oss in the chimpanzee. Int J Periodontics Restorative Dent. 1998 Jun;18(3):227-39. [Medline: 9728105 ]

17. Valentini P, Abensur D, Densari D, Graziani JN, Hämmerle C. Histological evaluation of Bio-Oss in a 2-stage sinus floor elevation and implantation procedure. A human case report. Clin Oral Implants Res. 1998 Feb;9(1):59-64. [Medline: 9590946] [doi: 10.1034/j.1600-0501.1998.090108.x] 
18. Piattelli M, Favero GA, Scarano A, Orsini G, Piattelli A. Bone reactions to anorganic bovine bone (Bio-Oss) used in sinus augmentation procedures: a histologic long-term report of 20 cases in humans. Int J Oral Maxillofac Implants. 1999 Nov-Dec;14(6):835-40. [Medline: 10612920]

19. Baslé MF, Grizon F, Pascaretti C, Lesourd M, Chappard D. Shape and orientation of osteoblast-like cells (Saos2) are influenced by collagen fibers in xenogenic bone biomaterial. J Biomed Mater Res. 1998 Jun 5;40(3):350-7. [Medline: 9570064] [doi: 10.1002/(SICI)1097-4636(19980605)40:3 3.0.CO;2-E]

20. Baslé MF, Lesourd M, Grizon F, Pascaretti C, Chappard D. [Type I collagen in xenogenic bone material regulates attachment and spreading of osteoblasts over the betal integrin subunit]. Orthopade. 1998 Feb;27(2):136-42. German. [Medline: $\underline{9530670]}$

21. Poumarat G, Squire P. Comparison of mechanical properties of human, bovine bone and a new processed bone xenograft. Biomaterials. 1993 Apr;14(5):337-40. [Medline: 8507776] [doi: 10.1016/0142-9612(93)90051-3]

22. Pappalardo S, Guarnieri R. In vitro osteogenic differentiation of mesenchymal stem cells on an highly purified bovine xenograft (Laddec®). J Biomater Tissue Eng. 2013 Apr;3(2):1-5. [doi: 10.1166/jbt.2013.1085]

23. Pappalardo S, Guarnieri R. Efficacy of Platelet-Rich-Plasma (PRP) and Highly Purified Bovine Xenograft (Laddec(®)) Combination in Bone Regeneration after Cyst Enucleation: Radiological and Histological Evaluation. J Oral Maxillofac Res. 2013 Oct 1;4(3):e3. [Medline: 24422036] [PMC free article: 3887574] [doi: 10.5037/jomr.2013.4303]

24. Guarnieri R, DeVilliers P, Belleggia F. GBR using cross-linked collagen membrane and a new highly purified bovine xenograft (Laddec) in horizontal ridge augmentation: Case report of clinical and histomorphometric analysis. Quintessence Int. 2015 Sep;46(8):717-24. [Medline: 25988192] [doi: 10.3290/j.qi.a34178]

25. Wallace SS, Froum SJ. Effect of maxillary sinus augmentation on the survival of endosseous dental implants. A systematic review. Ann Periodontol. 2003 Dec;8(1):328-43. [Medline: 14971260] [doi: 10.1902/annals.2003.8.1.328]

26. Wallace SS, Froum SJ, Tarnow DP. Histologic evaluation of a sinus elevation procedure: a clinical report. Int J Periodontics Restorative Dent. 1996 Feb;16(1):46-51. [Medline: $\underline{8631610]}$

27. Chiapasco M, Zaniboni M, Rimondini L. Dental implants placed in grafted maxillary sinuses: a retrospective analysis of clinical outcome according to the initial clinical situation and a proposal of defect classification. Clin Oral Implants Res. 2008 Apr;19(4):416-28. [Medline: 18266875] [doi: 10.1111/j.1600-0501.2007.01489.x]

28. Jensen OT, Shulman LB, Block MS, Iacono VJ. Report of the Sinus Consensus Conference of 1996. Int J Oral Maxillofac Implants. 1998;13 Suppl:11-45. [Medline: 9715571]

29. Pjetursson BE, Tan WC, Zwahlen M, Lang NP. A systematic review of the success of sinus floor elevation and survival of implants inserted in combination with sinus floor elevation. J Clin Periodontol. 2008 Sep;35(8 Suppl):216-40. [Medline: 18724852] [doi: 10.1111/j.1600-051X.2008.01272.x]

30. Rosen VB, Hobbs LW, Spector M. The ultrastructure of anorganic bovine bone and selected synthetic hyroxyapatites used as bone graft substitute materials. Biomaterials. 2002 Feb;23(3):921-8. [Medline: 11771712] [doi: 10.1016/S0142-9612(01)00204-6]

31. Artzi Z, Weinreb M, Givol N, Rohrer MD, Nemcovsky CE, Prasad HS, Tal H. Biomaterial resorption rate and healing site morphology of inorganic bovine bone and beta-tricalcium phosphate in the canine: a 24-month longitudinal histologic study and morphometric analysis. Int J Oral Maxillofac Implants. 2004 May-Jun;19(3):357-68. [Medline: 15214219]

32. Garetto LP, Chen J, Parr JA, Roberts WE. Remodeling dynamics of bone supporting rigidly fixed titanium implants: a histomorphometric comparison in four species including humans. Implant Dent. 1995 Winter;4(4):235-43. [Medline: 8603133] [doi: 10.1097/00008505-199500440-00002]

33. Russell JL, Block JE. Clinical utility of demineralized bone matrix for osseous defects, arthrodesis, and reconstruction: impact of processing techniques and study methodology. Orthopedics. 1999 May;22(5):524-31; quiz 532-3. [Medline: 10348114]

34. Takikawa S, Bauer TW, Kambic H, Togawa D. Comparative evaluation of the osteoinductivity of two formulations of human demineralized bone matrix. J Biomed Mater Res A. 2003 Apr 1;65(1):37-42. [Medline: 12635152] [doi: 10.1002/jbm.a.10345]

35. Piattelli M, Favero GA, Scarano A, Orsini G, Piattelli A. Bone reactions to anorganic bovine bone (Bio-Oss) used in sinus augmentation procedures: a histologic long-term report of 20 cases in humans. Int J Oral Maxillofac Implants. 1999 Nov-Dec;14(6):835-40. [Medline: 10612920]

36. Orsini G, Traini T, Scarano A, Degidi M, Perrotti V, Piccirilli M, Piattelli A. Maxillary sinus augmentation with Bio-Oss particles: a light, scanning, and transmission electron microscopy study in man. J Biomed Mater Res B Appl Biomater. 2005 Jul;74(1):448-57. [Medline: 15889429] [doi: 10.1002/jbm.b.30196]

37. Kawaguchi H, McKee MD, Okamoto H, Nanci A. Immunocytochemical and lectin-gold characterization of the interface between alveolar bone and implanted hydroxyapatite in the rat. Cell Mater. 1993;3:337-50.

38. Brunski JB, Puleo DA, Nanci A. Biomaterials and biomechanics of oral and maxillofacial implants: current status and future developments. Int J Oral Maxillofac Implants. 2000 Jan-Feb;15(1):15-46. [Medline: 10697938]

39. Hemler ME. Integrins. In: Kreis $\mathrm{T}$, Vale R, editors. Guidebook to the extracellular matrix and adhesion proteins. New York: Oxford University Press; 1993. p. 143-5.

40. Hynes RO. Integrins: a family of cell surface receptors. Cell. 1987 Feb 27;48(4):549-54. [Medline: 3028640] [doi: $10.1016 / 0092-8674(87) 90233-9$ ] 
41. Ruoslahti E. Integrins. J Clin Invest. 1991 Jan;87(1):1-5. [Medline: 1985087] [PMC free article: 294975] [doi: 10.1172/JCI114957]

42. Clover J, Dodds RA, Gowen M. Integrin subunit expression by human osteoblasts and osteoclasts in situ and in culture. J Cell Sci. 1992 Sep;103 (Pt 1):267-71. [Medline: 1429908]

43. Gohel AR, Hand AR, Gronowicz GA. Immunogold localization of beta 1-integrin in bone: effect of glucocorticoids and insulin-like growth factor I on integrins and osteocyte formation. J Histochem Cytochem. 1995 Nov;43(11):1085-96. [Medline: 7560891$]$

44. Hughes DE, Salter DM, Dedhar S, Simpson R. Integrin expression in human bone. J Bone Miner Res. 1993 May;8(5):

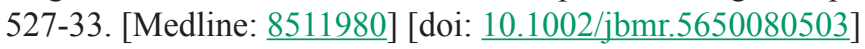

45. Zambonin-Zallone A, Teti A, Grano M, Rubinacci A, Abbadini M, Gaboli M, Marchisio PC. Immunocytochemical distribution of extracellular matrix receptors in human osteoclasts: a beta 3 integrin is colocalized with vinculin and talin in the podosomes of osteoclastoma giant cells. Exp Cell Res. 1989 Jun;182(2):645-52. [Medline: 2542071] [doi: 10.1016/0014-4827(89)90266-8]

\section{To cite this article:}

Guarnieri R, Belleggia F, Ippoliti S, DeVilliers P, Stefanelli LV, Di Carlo S, Pompa G.

Clinical, Radiographic, and Histologic Evaluation of Maxillary Sinus Lift Procedure Using a Highly Purified Xenogenic Graft $\left(\right.$ Laddec $\left.^{\circledR}\right)$

J Oral Maxillofac Res 2016;7(1):e3

URL: http://www.ejomr.org/JOMR/archives/2016/1/e3/v7n1e3.pdf

doi: $10.5037 /$ jomr.2016.7103

Copyright (C) Guarnieri R, Belleggia F, Ippoliti S, DeVilliers P, Stefanelli LV, Di Carlo S, Pompa G. Published in the JOURNAL OF ORAL \& MAXILLOFACIAL RESEARCH (http://www.ejomr.org), 31 March 2016.

This is an open-access article, first published in the JOURNAL OF ORAL \& MAXILLOFACIAL RESEARCH, distributed under the terms of the Creative Commons Attribution-Noncommercial-No Derivative Works 3.0 Unported License, which permits unrestricted non-commercial use, distribution, and reproduction in any medium, provided the original work and is properly cited. The copyright, license information and link to the original publication on (http://www.ejomr.org) must be included. 